\title{
19. 水循環システムの構築
}

Water Recycle Systematic

畔楖 剛*

Tsuyoshi KUROYANAGI

\begin{abstract}
Moden waterworks in Japan have a history of a little over 100years. With deterioration of the source water quality,complaints about smelling or untasty water are increasing in recent years. Supplying safe and good water may well be said to be the greatest mission of water services. The first condition for supplying safe and good water is to keep water resources good quality,but it is not an easy job in realty. In big cities and surrounding areas,ect.,advanced water treatment has come to be introduced by many water utilities, from the view points of prevention of damage due to unusual smell and reduction of trihalomethane.
\end{abstract}

KEYWORDS : recycle,water quality,

\section{1. 我が国の水资源の利用と再生}

水道は、循環源である水を利用するものであり、より良好な原水を安定して得るため には、水の偱環系が健全に機能していることが重要である。健全な水循環の镜点からは、 水源の水質管理の強化、水资源の効的な利用・調整の推進、取排水体系の見直し等の施 策につき、関保者との連㩲を强化し、維合的な取り組みを推進する必要がある。

また、これらの取り組みを通じて、上下水逆によって形成される人為的な水循環も含め た流域の総合的な水管理について、水道の立埸からも糟極的に検时する必要がある。

現在、全国で年間約 171 億 $\mathrm{m} 3$ の水が生活用水として使用され、この約 $2 / 3$ が全国 の下水処理場で処理されている。今後下水道の普及拡大に伴い下水処理水の量はますます 增えていくことが見込まれる。また、下永道は、都市に降る雨水を河川等人排水する機能 もあり、良好な水循環の維持・回得のため、丽水の污淘角荷の除去や貯留、利用にも取り 組んでいくことが必要である。このように今媵の水徣環の中で下水道の果たす役割は、質

・量ともにますます增えるので、稆極的に取り組儿でいくことが求められる。

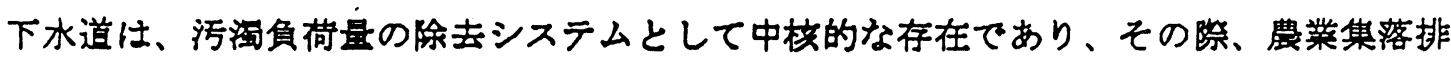
水施設、コミュニティプラント、合併好理净化槽という下水道以外の生活排水好理施配や 河川浄化施設等と連接しつつ、水質保全施策を展開していく必要がある。

また、地域や社会の要晴に忘し、下水処理水は水资源として積極的に活用を図るべきで ある。

特に、各地域の人口・庶業の分布によって、水循渨が果たす下水道の役猎も異なってく るので、地域の状況を十分配虑していくことが必要である。

*(株) シーメーアイ技術部 Sieiai Civil Engineering， Harisakicho

Higashikannji 36-33, Okazaki-shi,Aichi,Japan 


\section{2.下水道の新たな公衆衛生の問題}

下水道の果たすべき役割としては、Oー157等病原性微生物の除去等が举げられる。

Oー157による健康被害のリスクを最小化するための施策のうち下水道の処理で担う 心゙き取り組みは、下水処理で通常採用されている塩素消毒により十分な隇菌が可能である ことから、患者発生や病原菌発見の情報に対応して下水処理水の消毒を強化できる施設・ 体制の整備が効果的であると考えられる。水道法第 22 条においてもぞのような場合、塩 素による消毒強化が定められており、避㒕残留盐素の基準は $0.2 \mathrm{mg} /$ 以上である。

次に、下水処理水の有効利用について述へると、下水処理水は従来、活用を考慮せずに 放流してきた。しかし、近年、処理レベルが向上し良好な処理水質が得られ、様々に利用 することが可能となってきている。一方、各種用水のための水需要が增大し、河川等の水 域環境を維持するための水量確保も必要となってきている。

また、大都市地域における震災、大渴水等、災害時に対する㒉えはいまだ十分とは言え ず、そのような時の生活の不便や都市機能の麻㾝をいかに防ぐかが課題として残されたま まである。したがって、下水処理水の積極的な活用を進める必要がある。

流域の水循環のあるべき姿は、行政の判断で決定するべきものではなく、関係行政機関、 利害関係者など、まず第一に住民の意見を反映したものでないといけない。

このような流域の水循環のあるべき努の実現のために下水処理水が必要である場合、下 水処理水上流䢙元事業等の下水処理水を必要な水域まで、送水・供給する事業を推進すへ きである。しかしながら、上流遥元された下水処理水が水道水源の補給水となる場合、安 全性確保が必要であり、そのためには、渴水時等の一時的な利用に留めたりすることも考 えるべきである。

3.地球環境からみた問題

次に、地球温暖化防止との関わりについて述べると、地球温暖化防止の観点はこれから の全ての都市基盤整備を進める踏の最重要な評価項目となるべきものである。下水道事業 でも、CO2 を始めとする温室効果ガスの排出抑制に努める必要がある。下水道事業での 対策としては、末利用エネルギーの活用を図る下水荆利用事業および消化ガス発電が既に 実施されてきており、それらの推進に加え、今後さらに省エネルギー的施設設計などに取 り組んでいくことが必要である。

都市の水面は、水の気化熱等の吸熱作用を有するので、都市のヒートアイランド現象を 緩和し、その結果、都市の空調に消費されるエネルギー量を削減して地球温暖化防止にも つながるのではないかと考える。したがって、水面の拡大を図るべきである。

また、下水道の建設費および維持管理費の增大をもたらすという意見があり、今後、地 球温暖化防止、ライフサイクルコスト等の稓点から総合的に検討寸べきである。

国際的な観点から見ると、水循環の中に位目付けられた下水道の役割は世界に共通であ ク、日本における先駆的下水道計画は国際協力の推進に役立つ材料となっていくと思われ る。 
4.おわりに

マクロスケールの水循環は地球全体をその舞台としており、その中で水循環が包含さ れ、それらは、主に水自体仕大気、海洋を介して、相互に影響を与えあっている。したが って、日本の各流域において良好な水循環が維持・形成されることは世界各地の流域の水 循環が良好に維持・形成されることと無関係ではなく、特に海を挟んだ近隣諸国とは関わ りが生じやすい。

近年、発展途上国において、生活排水が未処理なことによる生活環境の悪化や水質污濁 の問題が深刻化し、我が国に対して途上国から下水道に関する技術協力の要請が急增して いる。

したがって、日本はそれらの要請に積極的に応えていく必要があり、その際には、各途 上国の状涚を十分に考慮し、良好な水循環を維持・回復する観点から検討したうえで我が 国の技術力と経験を活かしていくことが必要である。 